\title{
QUEEN'S
UNIVERSITY
BELFAST
}

\section{The Quality of Mutuality: Jazz Musicians in the Athenian Popular Music Industry}

Tsioulakis, I. (2013). The Quality of Mutuality: Jazz Musicians in the Athenian Popular Music Industry. In F. Holt, \& C. Wergin (Eds.), Musical Performance and the Changing City: Post-industrial contexts in Europe and the United States. (pp. 200-224). Routledge Taylor \& Francis Group.

https://www.routledge.com/products/9780415644860

Published in:

Musical Performance and the Changing City: Post-industrial contexts in Europe and the United States.

Document Version:

Peer reviewed version

Queen's University Belfast - Research Portal:

Link to publication record in Queen's University Belfast Research Portal

Publisher rights

(C) 2013 - Routledge

This is an Accepted Manuscript of a book chapter published by Routledge in Musical Performance and the Changing City on 03/04/2013, available online: https://www.routledge.com/products/9780415644860

\section{General rights}

Copyright for the publications made accessible via the Queen's University Belfast Research Portal is retained by the author(s) and / or other copyright owners and it is a condition of accessing these publications that users recognise and abide by the legal requirements associated with these rights.

Take down policy

The Research Portal is Queen's institutional repository that provides access to Queen's research output. Every effort has been made to ensure that content in the Research Portal does not infringe any person's rights, or applicable UK laws. If you discover content in the Research Portal that you believe breaches copyright or violates any law, please contact openaccess@qub.ac.uk. 


\section{The quality of mutuality: jazz musicians in the Athenian popular music industry}

Ioannis Tsioulakis

\section{Introduction}

It was during an introductory course in 1998, my first encounter with ethnomusicology, that I stumbled upon the idea that quality judgments in music are cultural constructs. The selected readings (Small, 1977; Blacking, 1973) demonstrated the central, if complex, role of musicality in the human condition. The idea that 'quality' in music was culture specific, however, was difficult for me to grasp. It wasn't so much the superiority of 'classical' music that I was concerned with; I was a mediocre classical pianist who had, early enough, switched to jazz. Nevertheless, accepting the fact that value judgments in music were only temporally and locally specific demanded the reconfiguration of my view of the Greek music scene in which I was becoming professionally involved. 'Quality' serves as a fundamental discourse within urban Greek music production. Musicians, audience, critics, press and popular media refer to 'musical quality' in variable and self-contradictory ways. Being immersed in this discourse since childhood provided my local colleagues and I with a quasi-ideological attitude as far as the evaluation of music genres and styles was concerned. Having to deconstruct these ideologues and analyze the cultural specificities that formulate them has proven to be the most challenging task of my research among Athenian professional musicians.

The discourse of 'musical quality' is inextricably connected to the Athenian urban context. The aesthetic sensibilities and modes of cultural consumption hosted in a city 
of such magnitude provide an (often cacophonic) plurality of music ideologues. Diverse cultural agendas compete over gaining attention and dominating public domains of various visibilities. Printed press, radio, television, and electronic media offer some of those domains, the operation of which depends on the scale of their influence: subcultural, 'mainstream', local, national, transnational and so on. In an epoch when live music performances regain their centrality in the music industry (Holt, 2010), music venues become nodal points for aesthetic negotiation. The ethnomusicologist of contemporary music scenes occupies a vantage observational point over this process. The sociality of live performances in urban music venues is where the dialog between the local and the translocal, the practical and the aesthetic, the real and the imaginary becomes vividly manifest. An ethnomusicological emphasis on performance is essential for the description of the changing modalities of these kinds of dialog, and the microcosms of urban music venues offer ideal terrains for such an examination.

This text will attempt an examination of the 'quality' discourse among jazztrained professional instrumentalists with whom I have collaborated as a musician and ethnomusicologist for a period of over five years. More specifically, my aim is to illustrate the connection between the sociality of performance, the space and sound circumstances within which it occurs, and the evaluation of musical experience by the participants of the diverse Athenian music scenes. In order to do so, I will focus on a specific group of musicians and their behavior in - and understanding of - three diverse performance occasions: (1) a series of gigs ${ }^{1}$ at an upscale bar-restaurant, (2) a one-off jazz gig at a small club and (3) a collaboration with a Greek pop-star at a large 'mainstream' nightclub. In the discussion of these case studies I will link the local discourses of 'energy flow' on stage with Victor Turner's theories of liminality and

\footnotetext{
${ }^{1}$ I am using the word 'gig' rather than 'concert' in accordance with its local use. My informants use 'gig' (the actual english word) to refer to an occasional performance or a brief series of concerts, opposed to a 'season' (saizón) which describes a steady weekly schedule of performances at a specific nightclub for a few months. A 'concert' (synavlía) would be used primarily for large-scale and usually open-air performances.
} 
communitas (1982). Finally, by examining the utterances of the musicians themselves and their positions of power within the given social structures, I will suggest a view of musical 'quality' depending on performative mutuality. As the following ethnographic examples will make clear, the term performative mutuality speaks to a particular ideal of music-making as seen through the subjectivity of instrumentalists and their quest for social empowerment.

In my examination of the 'quality' discourse, I employ a sociomusical focus, which, according to Steven Feld, describes a concern with the aural dimension of any 'intersubjectively created world of actors and actions' (1984: 404) and the role of the interplay between local ideologies and music in creating and maintaining such worlds. Marina Roseman, in her application of Feld's sociomusical comparative model has highlighted the significance of 'the strategies of sound in use' (1984: 411) and the way that they reveal individual and collective agency related to the reinforcement or inversion of existing social worlds.

In accordance with the above perspectives, I intend to investigate the way in which the 'quality' discourse is socially, spatially and sonically performed and examine the participatory dynamics that define it. Each of the case studies that I will narrate illustrates different modes of sociality and music participation seen through the experienced subjectivity of a specific caste of instrumentalists. Each venue brings together a unique combination of people who are bearers of contradictory cultural aesthetics and eager to negotiate and impose their ideologies in various ways. The example of Athenian jazz musicians provides a stable point of view over the diversified music industry. Although not unique in their attitudes, Athenian jazz musicians offer through their ardent ideas of musical value and intense criticism, a valuable account of the clash between the dissimilar agents of the music scenes. Their musical idealism, connected to an imagined transnational community of jazzmen, yet contradictory to the 
performing circumstances within which they often find themselves operating, speaks to the way in which urban music identities are constructed, projected, and negotiated.

The last two decades of the twentieth century have witnessed an increase in the popularity of jazz music among professional musicians and students in Athens. Since the early eighties, young musicians of all classes and backgrounds left for Western Europe and North America to pursue systematic training in their favorite music. Others chose to stay in Athens and learn through obsessive album collecting and vigorous practicing. By the early nineties, conservatory departments specializing in jazz music education had started to appear, ensuring that a significant number of talented young jazz musicians existed in the Greek capital. Understandably, it wasn't long before this cast of musicians started to seek employment. The enthusiasm of trained instrumentalists for jazz music was not, however, matched by the general audience's preferences. Despite the numerous initiatives by Athenian jazz aficionados, including recording efforts, organization of various festivals, and the existence of a dedicated radio station throughout the nineties, jazz music never managed to develop into more than a subculture driven by a limited local intelligentsia. ${ }^{2}$

The fact that the number of jazz-trained instrumentalists was much larger than the small circuit of jazz music enthusiasts could support, led them to seek employment in the popular music industry. The Greek music industry is mainly dominated by three genres: (1) urban-folk (laikáa) ${ }^{3}$, which is usually described as a modernized version of rebétiko music, (2) pop, which largely includes westernized hit-songs, and (3) art-song (éntehno) which resembles those singer-songwriter styles developed in Italy and France

\footnotetext{
${ }^{2}$ For a more detailed discussion of the development of a jazz scene in Athens, as well as some empirical data of the aesthetic debates that accompanied it, see Tsioulakis, 2011a.

3 Although the immediate translation of the term laikó (pl. laikâ) is 'folk,' I use the term urban-folk to distinguish the urban musical culture of laiká from paradosiaká (traditional), a term used to refer to rural folk music. The musical culture of laiká is seen in urban Greece as being evolved from rebétiko song rather than from rural folk music. For two recent ethnographic approaches on the revivals of rebétiko and paradosiaká in the Greek urban centres, see Tragaki (2007) and Kallimopoulou (2009).
} 
yet localized by incorporating Greek orchestration ${ }^{4}$. The three genres are represented by different artists, promoted by separate media (magazines, radio stations, TV shows) and, especially in the nineties, were followed by mutually exclusive and ideologically opposed fan groups. Their performative practices, however, are quite similar. The vast majority of local popular music production is sung in Greek, and therefore does not necessarily aim for an international market. Consequently, Greek popular music stars rely solely upon the support of intra-national audiences. In order to maintain their popularity among those audiences and earn financial profit they tend to perform at fixed Athenian nightclubs for seasons that start in autumn and generally last until spring. During the summer they tour the rest of Greece or play for Greek audiences abroad. The music industry of the 'mainstream' genres is balanced by the existence of various 'alternative' scenes (enallaktikés skinés) of rock, metal, funk, hip-hop, jazz music and their subgenres. Paradoxically, these music subcultures appear keener to incorporate cosmopolitan traits, such as the practice of singing in English, than their 'mainstream' counterpart. $^{5}$

The above situation offers two employment options for jazz-trained musicians. The first is to form cover bands and play within the 'alternative' circuit of clubs, thus remaining 'faithful' to their initial aesthetic preferences. The second option is to be in the service of a specific 'mainstream' pop singer for a season. This choice, although often viewed as a severe compromise, results in far more generous salaries and increases the musician's recognition within the mainstream music industry. Most instrumentalists undertake both options simultaneously or successively. Jazz musicians in Athens have to move through these contexts in a cultural and physical sense. The various genres are hosted in settings that serve different, sometimes contradictory, ideologies, affiliations

${ }^{4}$ See Cowan (1993) and Papanikolaou (2007).

${ }^{5}$ For a discussion of cosmopolitanism within the Athenian jazz subculture, see Tsioulakis (2011a). 
and power structures. While jazz musicians shift through some or all of them, they negotiate their ideological and aesthetical dissonance with the performative events.

In order to exemplify the way in which instrumentalists experience and articulate their mutual participation in these different sites of music production and consumption, I will now focus on a specific band called Rustik. ${ }^{6}$ By examining three specific examples of communal music-making from the band's history, I will delineate links between their understanding of 'quality' in musical performance and the changing conditions of their mutual engagement with the event, its entrepreneurial actors, and the audience. While looking at the participatory dynamics of each setting, I will show how the inherent negotiations of power lie at the center of the band members' evaluation of the music, their pleasure, and perceived creativity.

\section{The story of Rustik}

When Mihális decided in the late nineties (and his late twenties) to leave New Jersey and move to Athens, his knowledge of Greek did not exceed a few sentences pronounced with a thick American accent. Although his band's recent dissolution in the States involved some hurtful incidents and rough exchange of words, he could not imagine himself being anything other than a rock lead-singer. His relocation to Greece was driven by a desire to reconnect with his cultural roots, accompanied by a hope of establishing himself as a singer in the local scenes. With his experience augmented by the authenticity of 'coming from America,' he soon found himself surrounded by eager young Athenian musicians who saw in his inability to speak Greek a unique opportunity

\footnotetext{
${ }^{6}$ All of the names of participants, bands, and venues have been changed due to the sensitive nature of some of the described events, especially since, at the time of writing, the discussed social tensions are far from being resolved.
} 
to advance their English. They went around proudly announcing that they're playing with this newly arrived American singer (funny, he was always 'the Greek' in New Jersey) called Mick. Despite his persistence in introducing himself as Mihális, he always ended up being called Mick; all these years his American friends couldn't pronounce his Greek name, now his Greek ones would not.

The band Rustik was subsequently formed by guitarist Bábis, bassist Níkos, drummer Thános and Mick as the lead singer and front-man. They played hundreds of gigs within a network of underground Athenian live music stages and bars as a cover band with an exclusively English-language repertoire. Even after Mick became fluent in Greek (a requirement dictated by the judges of a popular televised talent-show, ${ }^{7}$ which featured Mick as a finalist in 2004), the band refused to include any Greek pop or rock songs in their repertoire. In the summer of 2004, Níkos, the bassist and unofficial musical director of the band, decided to leave them. He was soon replaced by Achilléas, a nineteen-year-old bass player (five years younger than Thános and Bábis, and fifteen years younger than Mick) who was just beginning to build a reputation around Athens as a promising young talent. The band continued to perform covers of non-Greek songs, a choice ensuring their popularity in small 'alternative' clubs around Athens but preventing a break into the mainstream Athenian music industry.

When, in the summer of 2005, I first joined them as a keyboard player, the band was ready to establish its first 'professional' collaboration by accepting an invitation to perform with E-, a mainstream female pop-singer. The agreement dictated that Rustik would play as an opening act at E-'s concerts, while the band's instrumentalists (in other words, everyone except Mick) would perform as E-'s backing orchestra for the main part of the show. E-'s show consisted of some of her songs that had made it

\footnotetext{
${ }^{7}$ Interestingly, this was a show designed to select the Greek contestant for the upcoming Eurovision Song Contest. In this context, Mick's fluency in English (the language of the contesting song) was perceived as one of his primary assets.
} 
into the Greek pop-music charts, in addition to other Greek hits. Moreover, the band was obliged to include some Greek pop songs into their own act. Rustik regarded this arrangement as an opportunity to reach wider audiences and increase their popularity while earning significantly more than in the small rock clubs. The disappointment over having to expand their repertoire towards previously discarded musical genres was overshadowed by the excitement caused by the appearance of new professional horizons.

This leap into the mainstream music industry proved to be the first of many. Since 2005, members of Rustik have performed diverse genres of music that matched their musical preferences in various degrees. Their increasing ability to transform their playing style according to the circumstances, along with the growth of their reputation as a backing band, enhanced their employment options and provided them with considerable experience. As a result, they learned how to cope with different working conditions, from the large pop-clubs to small live-stages and the webs of power they each entail. While shifting through musical terrains they were not only trained to adjust to the performance requirements, but also to relate to their employers, their various audiences, and each other in different ways.

\section{'Unplugged Tuesdays' at the Alma Libre Club}

The beginning of Rustik's professional career brought a significant change to the band's dynamic. Their occupation as a backing orchestra for established pop singers meant that the instrumentalists would spend some time on stage without Mick's presence. This division of the band's duties between, on the one hand, being an independent group in their own acts with Mick and, on the other, serving as backing musicians who, without Mick, performed according to the occasional pop singer's demands, triggered a 
separation between the instrumentalists and their Greek-American front-man. The working part of music-making, which mostly comprised the rehearsals dedicated to the pop star's act and the arrangement of his or her songs, happened in the absence of Mick. As soon as Thános, Bábis and Achilléas realized that the music industry was in need of young (read also: cheap), knowledgeable, and eager instrument-players like themselves, they did not hesitate to avail of these employment opportunities. While Rustik continued, its members simultaneously started to work in other settings and in diverse configurations, without necessarily advertising the band on every occasion. Rustik as a band name was used more among the musicians as a signifier of their common life courses than as an external identification.

In one of these instances, I was called to perform with them at the Alma Libre Club. Twelve well-paid weekly gigs were anticipated from the beginning of June until the end of August 2008. The owner wanted the band to perform acoustic covers of popular hits for two sets of about an hour each. He promoted the series under the title Unplugged Tuesdays at Alma Libre. Achilléas, who stepped up as musical director of the event, was in charge of the gig's set-list, the negotiations with the entrepreneurs, and the sound arrangements. On the other hand, Thános, Bábis and I were to learn our music parts, show up at the gigs on time, perform, get paid, and leave. ${ }^{8}$ Everyone saw this arrangement as a creative prospect. After all, they had been trained in jazz for years, and this acoustic mode of playing served as a good excuse for them to sneak some jazzy arrangements into their playlist.

The location of the Alma Libre Club was far from 'picturesque.' It was situated in an overpopulated urban neighborhood, visually dominated by a giant football pitch and a cement school building. Not surprisingly, the club was designed and decorated in such a way that prohibited any visual contact with its blunt surroundings, while the open

\footnotetext{
${ }^{8}$ Not insignificantly, the band comprised two female singers and four male musicians. This is illustrative of a gendered division of musical labor typical within the Athenian music scenes, where professional instrumentalists are almost exclusively male, while women mainly participate as singers.
} 
roof only permitted a view of the night sky. In order to be admitted into the club, the paying customer first needed to pass through the door-screening process. This procedure ensured that only customers who had a reservation and fitted the desired profile of the clientele would enter the club. ${ }^{9}$ The venue was defined by a transgeographically cosmopolitan, baroque-style decoration. The luxurious graven furniture, velvet curtains, and shiny mirrors contributed to a posh atmosphere of an intentionally unspecified locality. As the musicians soon realized, the acoustic/unplugged character of the event, while aesthetically suitable for the relaxed yet unmistakably upper-class setting, was dictated by the fact that the club did not hold a legal permit for live music performances. The management sought to keep the event literally quiet, an attempt further handicapped by the open-air setting. On the first two occasions, the gigs were interrupted by the arrival of the police investigating neighbors' complaints about the loudness of the music. Several warnings to Thános, the drummer, to play more gently, even though he was already using brushes instead of sticks and, according to his claims, was 'playing as softly as humanly possible,' led him during the third gig to turn his chair around and start playing on a plant instead of his drums, in complete mockery of the management's indications and the whole event. Eventually, the musicians were relocated to an isolated part of the club that resembled a private lounge more than a stage. This new configuration made the music hardly audible outside the club's walls, with the side-effect of physically separating the band from the audience to an extent that prevented the majority of the customers from any visual contact with the performers.

A remarkable incident took place on the night of the fourth gig. The members of the band showed up and started setting up their equipment just after $10 \mathrm{pm}$ as usual. The gigs normally started around midnight and went on until 2 am. But this time,

\footnotetext{
${ }^{9}$ A guest of the musicians was once refused entry on the grounds that he did not have a reservation, while the club was fairly empty. He maintains that his rejection had to do with his long dreadlocks.
} 
around $11 \mathrm{pm}$, Achilléas announced to the rest of the musicians that the club's management did not want them to start their session until 2 am. The proposed explanation was that a VIP customer from abroad was visiting the club. This guest was apparently mourning and did not want any live music to be played until after he left. As a result, the band left the venue and did not return until $1.30 \mathrm{am}$. When I entered the club for the second time that night, I found them discussing the incident. Below is the conversation between Achilléas, Bábis, Thános and myself translated from my field notes:

Ioannis: So, what's happening guys, what time are we playing?

Achilléas: Don't know man, still waiting for the manager to tell me.

Ioannis: Do we know if we're even playing at all?

Achilléas: I think we should play at least one set.

Bábis: What's that whole story with the mourning? Sounds ridiculous! The

DJ is playing so loud - pumping dance music! This is not a mourning place...

Achilléas: Yeah, we kind of believe this mourning thing is a load of bullshit.

There's something else going on.

Ioannis: Who's the VIP?

Achilléas: It's L-'s (famous Greek ship-owner's) daughter and a friend of hers from abroad or something [...] They might have asked for no band 'cause they didn't want any live music at all, or maybe it was the management who thought it would be better if they cancelled the gig. Don't know whose call it was. I still think, though, that we should play at least one song! Go up, play one of each singer's songs, say goodnight and go.

Bábis: Why would we do that, Achilléas? That sounds stupid. Why don't we just pack and go home?

Achilléas: 'Cause we don't want to give them any 'reasons'. 
Bábis: Reasons for what?

Achilléas: Not to pay us, man!

Although later that night they were ordered not to perform at all, the band still received full payment. The collaboration was, however, terminated at the end of July when the Alma Libre Club announced a new event schedule and cancelled the four remaining gigs. When asked about his experience of working there, Achilléas commented:

Easy money and challenging enough because they made us play in an acoustic style which we had never done before. But it eventually really let us down. There was no communication or response from the audience and, after a point, we didn't even want to show up there and play!

Bábis, on the other hand, focused on mostly positive memories:

I actually enjoyed being in our little corner. We had done a lot of work and had nice covers [...] I liked the jazzy sound too! [...] I didn't mind the lack of communication with the audience, although I know that Thános found it really disappointing.

The target of the band's most severe criticism was the management of the club who was seen as exercising their power over the performance context in order to make the band's experience the least creative and meaningful possible.

The bar's management created a situation where I could not communicate in any way with the audience. The people who called the shots used all their power to stop the flow of energy from the musicians to the audience in order 
to turn the band into a mere background atmosphere maker. [Thános drummer]

The specific night that the band got paid for not performing was also raised in subsequent private interviews. When asked to elaborate on the way that the incident affected their perception of the event and their positions in it, they responded:

If it was a gig that I really wanted to play I would have been very upset for getting paid not to play. But it wasn't there to play. I was there to perform some songs in a specific way, and make people enjoy their drinks with a good background sound. I was more like a decorative flowerpot. [Achilléas]

I felt awful. The person who gave that order made me feel like an unnecessary decorative element that he could remove whenever suited him. [Thános]

The common use of words such as 'background' and 'decorative' is far from coincidental. These words are widely used among Athenian instrumentalists to sum up their frustration and fears towards the role they are expected to assume in the diverse performative loci of the popular music industry.

The above statements suggest that the event lacked the audience's appreciation of the music. The musicians, however, disagree over the importance of this factor for their enjoyment. By asserting that the physical isolation of the band ('our little corner') was an enjoyable factor, Bábis attached no significance to the interaction with the audience. With this declaration he is not reducing the importance of mutual participation and engagement in the performance, but rather he excludes the audience from it. For Bábis, 'our little corner' represents a spatial arrangement that facilitates the communication between the band members by blocking out all restrictive interference. 
In a very similar way, Howard Becker has illustrated how a spatial segregation was welcomed by American jazz musicians in the 1940s since 'direct contact with the audience can lead only to interference with the musical performance.' (Becker, 1951: 142) Becker's informants portrayed audiences as composed of ignorant 'squares,' the interaction with which was potentially dangerous for the musician's integrity and creativity.

On the other hand, Thános and Achilléas consider the audience's attention and approval crucial for their pleasure. Thus, the physical barriers between the performers and the audience, and the management's attempts to reduce the music's character to background sounds ensured the impossibility of an experience of mutuality. In an article discussing the performances of a group of professional jazz musicians in Zurich, Avron Levine White (1987) reports a similar case of arguments between the band and the bar employees over the sound volume. White's informants portray loudness as an essential prerequisite for 'winding people up' and 'getting them into the music' (1987: 195); his conclusions reveal striking parallels to my own observations.

This first case study exemplifies the impact of the spatial and sonic aspects of the performance on its sociality. Its loudness and spatial configuration serve as grounds for a power struggle between musicians and club owners. As both the observation of the episodes and the musicians' utterances reveal, this is a micro-struggle for domination: whoever controls the space and sound, controls the performance. For the instrumentalists who 'lose' the battle, this is neither their space nor their sound. Regula Qureshi's (1987) influential performance model for musical analysis has focused on the vantage point of the performer who is perceived as the key modifier of a music event. In her view, the performance is defined by an interaction between the musicians and the audience who 'operationalize' music and context respectively (1987: 63). Although I agree that the performer's vantage point offers the richest—albeit not sole-terrain for analysis, I find Qureshi's bipolar model of performer and audience overly simplistic 
to account for the social significance of space and sound in the performance. The conflict over the domination of these two performative aspects illustrates that they are only ideally governed by musicians, while the loss of control over those components precipitates an experience of alienation. Qureshi's performance model, with its emphasis on the micro-strategies of live music-making and its sensitivity to the dynamics of participation, can be enormously useful for an ethnomusicology of urban musicking. It needs, however, to be further developed in order to address the changing social circumstances within the centers of cultural production. This entails an additional attention to the dynamics of entrepreneurialism. In the presented power play, the most significant agents are the club's managers who succeeded in converting themselves from mere mediators to crucial performative actors.

For the instrumentalists involved in the Alma Libre Club series, the event entailed a limited engagement with values attached to musical interactivity and sociality, and thus epitomized a failed performance. The musicians' intention to disassociate themselves from the produced music is further shown by the references to payment, which in this context contribute to an understanding of the event as primarily a financial endeavor. As both the interviews and the discussions suggest, focusing on payment serves as a means to detach themselves from the event's inherent mechanisms of control. In other words, by stressing their financial benefits, the instrumentalists conceptualize their engagement as laboring, an etiquette making their frustration as creative musicians more bearable. The grounds on which the musicians build their criticism, however, are not provided by the music per se. They all admittedly enjoyed the 'jazzy' playing style, the chosen set list, and the acoustic arrangement of the band. Their disappointment gushes from the failure of the social circumstances to foster what was initially envisaged to be quality music-making. It was, therefore, their ideal of performative mutuality that the events failed to achieve. 


\section{The No-setlist Transatlantic Project.}

During the week after the cancelled gig at the Alma Libre Club, a friend of Rustik was visiting Athens. Iákovos, a talented young jazz guitarist, was a classmate of Thános and Bábis from secondary school who had left Athens several years earlier to study and work as a musician in Los Angeles. Every time Iákovos planned a visit to Athens he would meet with his friends to catch up on their news. The meetings always concluded with a long improvised music session. This time, Iákovos took the freedom to book a gig at a small music stage called The Attic, which had a last-minute cancellation and was desperately looking for a band to play. He assured his band-mates that the event would not require more than one rehearsal as the concert was to celebrate freedom, improvisation, and 'expressive communication' between reunited friends.

Under these circumstances, Iákovos, Thános, Achilléas, and I found only one commonly suitable hour for rehearsal in order to agree on the tunes and their rough sequence in the concert. We played a few themes and arranged the basic rhythm patterns and keys. The rest of the event's fate was left to momentary creativity, a fact that caused more excitement than worry. Since the concert was only two nights away, little advertisement was attempted. The No-setlist Transatlantic Project, as a name for the event, seemed to do justice to the lack of preparation while simultaneously playing on Iákovos's return visit from the States. A quick announcement on web-based social networks ensured the presence of everyone's closest friends, which would, without doubt, serve as enough of an audience for the small music stage.

On the evening of the concert, we arrived at the venue to set up the equipment and check the sound. The Attic, as the name reveals, was a small music stage located in the upstairs section of a bar in Psiri, an area within the historical center of Athens with an extremely busy nightlife. Despite the bar's central location, the lack of visibility from the street, along with the absence of uniformity between the hosted music acts, ensured 
that the audience almost exclusively comprised fans and friends of the featured band. Upon our arrival at The Attic we realized that another band was scheduled to play prior to us on the same night. After a brief discussion with the owner of the venue, Iákovos informed us that, due to some misunderstanding, a band had been called to play as our support act. He described them as 'complete amateurs, who don't even have their own amplifiers and they're asking if they can use ours!' The situation was deemed unacceptable by everyone for two main reasons: (1) the professional musicians were reluctant to allow 'kids to mess up with their equipment,' and (2) they had invited so many people to the event, advertising it as a single act with Iákovos's special appearance; the idea of putting their audience through the hardship of listening to some amateur band for an hour before they played seemed outrageous.

Achilléas and Iákovos proposed instead that our act should take place first at the advertised time and, after its ending, the 'student band' could play using the venue's equipment. This proposition was accepted by the owner as it was reinforced by the excuse that two musicians (Thános and Achilléas) needed to 'catch a plane in the early morning for a gig with T- (famous female pop singer) in Northern Greece.' This excuse, albeit true, would not normally have been strong enough to alter the established practice of every concert, namely that the 'weakest' band plays first. It did, however, include a hidden connotation: by stating that they were flying for a gig with a famous singer in the morning, Thános and Achilléas did not stress their inability to stay up late, as much as they hinted at their advanced professional status as musicians. Their recognition as professionals in their milieu endowed them with the power to make decisions to which neither the owner of a small music club such as The Attic nor an 'amateur band' could object. Their musical professionalism was significant because music was the central spectacle in this venue, compared to its 'background' function in the Alma Libre Club. 
The second act in this power game was played out during the sound-check. Thános was the first to sit at the drums. After a few beats he decided that the drum set's quality and condition was intolerable. The bass drum sounded 'worse than what an empty can of feta-cheese would sound if I could attach a pedal to it.' When the young drummer of the other band responded 'well, we'll have to make the best out of it, right?', Thános, theatrically ignored her and immediately called his brother to arrange for parts of his own drums to be brought to The Attic. Even though this decision precluded the possibility of proper sound-checks for both bands since the time was already running late, Thános was of the opinion that playing with suitable drums was more important than having the sound thoroughly configured. Significantly enough, in the specific setting, he was capable of imposing such decisions. Achilléas checked the sound of his electric bass, Iákovos, tuned his guitar, I connected my keyboards and then the three of us played a few seconds of a funk-jazz theme with a straightforward chord progression to ensure there were no major issues with the sound setup.

When the drums were delivered half an hour before the programmed start of the concert, the audience had already started to congregate. During the first two pieces the sound was still being adjusted, but everything worked smoothly for the rest of the concert. The four band members (including myself) were enjoying the performance enormously. The affirmative gestures and shouts being exchanged between the players on stage along with the cheers of the audience after every single solo created an intense atmosphere of pleasure and euphoria. Most of the members of the audience seemed to understand the musical conventions: solo choruses and climaxes, groove alterations, and improvisational techniques. This made their 'knowledgeable' reactions more encouraging for the instrumentalists. The music grew successively louder, the improvisations longer, the grooves tighter ${ }^{10}$ and the affirmative signals between band

\footnotetext{
${ }^{10}$ A 'tight' groove, where rhythm patterns and music riffs interlock resulting in a sense of effortless synchrony, is cross-culturally proposed by jazz musicians as a key characteristic of successful band cooperation. It is not coincidental that Greek musicians frequently use the term 'tight groove'in English.
} 
members more frequent. The bar was extremely crowded, warm and smoky, a fact that did not seem to affect the collective enjoyment. The performance lasted roughly one hour and a half, with the participation of several members of the audience who took the opportunity to 'jam,' occasionally replacing a member of the band. This confirmed my initial suspicion that we were not the only trained musicians in the venue. The musical involvement of audience members, combined with the fact that the stage was not physically demarcated in any way, successfully blurred the distinction between 'official' performers and spectators. After the end of the act we gathered our equipment and cleared the stage for the next band. At that moment, the owner of The Attic approached Iákovos and I in order to reiterate his apologies for causing such an inconvenience. He exclaimed that he was not aware that he was 'dealing with real professionals.' He assured us that his bar would be available anytime that we wished to book another gig. Interestingly enough, none of the band members ever enquired about payment or percentages of the tickets.

During later private interviews, the instrumentalists were asked to comment on this event and its significance to them:

It's musically amazing, you free yourself and play the way you feel, you test and challenge your communication with the other musicians. [Achilléas]

It was incredible. That's the closest it gets for me to the ideal performance. The freedom of playing, the interaction among the band members, the communication with the audience, the flow of energy. [Thános]

Ingrid Monson (1996) and Charles Keil (1994) have elaborated on the significance of 'grooving' together as both a technique in music and a social metaphor. 
Both of the musicians' comments stress the importance of 'freedom.' Their idea of 'freedom' is presented as purely musical, it would be impossible, however, to ignore its relevance to the surrounding social dynamics. Their artistic, expressive freedom resulted from their ability to shape the performative conditions: when to play, which instruments to use, and how to present themselves. The spatial and sonic features of the performance were recognized by the musicians as crucial parameters that needed to be dominated. Their control over the technology used (their sound equipment that the other band should not be allowed to use, their 'better' instruments) and the spatial arrangement, inevitably brought the performers to the center of attention. This was their space, their sound and ultimately their performance. Richard Schechner has noted the performative importance of light and darkness in directing attention to the stage and limiting the time span of intra-audience communication to intermissions. (1988: 179) I would argue that sound, and in particular its volume, operated here in a similar way by regulating the time when members of the audience were able to hear each other.

In these circumstances, the band's unconcern about financial gains is indicative of an understanding of their experience as autotelic: one that does not require any rewards outside itself. In other words, by not claiming their payment, the musicians exemplify their view of the specific performance as play rather than work. ${ }^{11}$ Csikszentmihalyi (1990), in his pioneering study of the psychology of 'flow' in games and leisure, has pointed out its 'autotelic' character as a crucial prerequisite. He describes the state of 'flow' as follows: 'alienation gives way to involvement, enjoyment replaces boredom, helplessness turns into a feeling of control, and psychic energy works to reinforce the sense of self, instead of being lost in the service of external goals.' (1990: 69) Following this, a request for payment would have diminished the importance of the flow experience by contradicting its autotelic essence, which was verified by the

\footnotetext{
${ }^{11}$ Christian, in his research among semi-professional British musicians has also noted their willingness to perform for smaller payments if it was for a 'jazz gig' since they would 'enjoy it.' (1987: 224)
} 
existence of the other elements: involvement, enjoyment and control. Nonetheless, it should be remarked that the musicians' capacity to act as power-holders and dominate the event came from their legacy as professionals within the pop industry. The experience of autotelic enjoyment thus becomes a more complex sociocultural matter than what Csikszentmihalyi's work suggests. By successfully illustrating their prominent professional rank the musicians portrayed the specific performance as a playful break from their otherwise acclaimed busy careers. In other words, they exercised the power granted by their association with mainstream stardom, a circuit that they themselves largely disregard. It was this power that essentially allowed them to transform the concert into a 'flow' experience.

This case sprung out of my interviews with the specific musicians as the closest example to their ideal of mutual engagement in performance. The strategies through which they shaped the sociality of the event, however, show how conscious they are of the specificities of the urban scene in which they operate. Their performance was driven by a cosmopolitan music aesthetic incorporating modalities of interaction and improvisation characteristic of jazz-derived styles. But in order to achieve that ideal, they had first to regulate the social factors that were likely to interfere with their desires. In this process they dealt with a local network of participants (bar owner, support band, audience) using locally specific assets (their reputation). This process illustrates an aspect of performative mutuality that transcends the idealistic overtones of a purely democratic and 'free' music-making. The achievement of 'energy flow', this case concurs, depends on the accumulation of symbolic capital (professionalism, recognisability) which can only be assessed through the hierarchies of the local music scene, even if the performed genre is, in its frame of musical reference, quintessentially cosmopolitan. It is through this interplay between the cosmopolitan and the local, the ideal and the achievable, that the concept of performative mutuality becomes meaningful in the examination of an urban music scene. 


\section{Working for a pop-singer}

At the end of July of 2008, Mick called all of the members of Rustik on the phone with a proposition for the winter season. For the past few years, Mick had been working as a backing vocalist for $\mathrm{S}$ - a famous Greek male pop singer, who was preparing a new show for the winter. The singer and his musical director, Mick claimed, had been convinced to employ Rustik as both an independent support act and a backing orchestra for the pop star. Mick, Achilléas and Bábis were excited about the prospect, while Thános was very skeptical. On the afternoon of 7 August, we met to discuss this arising matter over coffee.

Mick and Achilléas argued that the offer marked an 'once-in-a-lifetime opportunity' for the band to receive media attention, build a fan base, and have a very profitable job for the winter. They also stressed the fact that $\mathrm{S}$ - had promised to use his influence with major music labels in order to establish a record contract for them. Thános, on the other hand, proposed that collaborating with such a big-shot, mainstream super-star' would be an opportunistic move having nothing to offer to Rustik's career as a rock band. He pointed out that Rustik had no original songs in their nine-year legacy as a band and he did not consider this sudden break into the music industry as an adequate reason to put together an album from scratch. Achilléas responded to Thános's last point that the situation resembled 'getting married to a girl because you got her pregnant.' He, nonetheless, did not consider this strategy as necessarily negative: 'let's say that you're in a nine year relationship with this girl and you love her! Her getting pregnant could be seen as the factor that finally encourages you to propose!' Thános, however, made clear his reluctance to participate and his intention to accept another offer and work for an alternative singer/comedian for whom he had 'a greater deal of respect as a person and an artist.' 
Thános eventually left Rustik a few weeks later and his friendship with Mick was irreparably damaged. Mick's justification for being offended was not based on Thános's decision not to participate but on the essence of Thános's logic that portrayed his bandmates as 'sell-outs.' At a later time I had a private discussion with Thános concerning the reasons for his disagreement and subsequent departure from the band:

Ioannis: Why did you object to the collaboration with S-?

Thános: Working for this singer aligns us with a circuit of very questionable quality. We have no idea what these people want from us, we only know that we won't be able to stop them from getting it!

Ioannis: Is it moral, laboring or musical quality that you are referring to?

Thános: It's musical. I don't trust the circuit that S- works for. I believe they're going for a one time collaboration that will pay them well and they don't really care about the musical quality of the whole project. T- [female pop singer] for example is sucked in by that circuit. She's such a brilliant singer but her songs say nothing to me, and she ends up playing for audiences that will go to the club to watch her ass move rather than hear the music or her voice.

What the above discussion clearly suggests is an idea of quality that is closely related to the idea of power. Thános's experiences of powerlessness in the first case study and control in the second have been conceptualized in close relation to the quality of the produced music. The power relations that mediate this third performance context are seen a priori as endangering the quality of the project, which, as the excerpt implies, can only be ensured by musically sensitive instrumentalists and not 'fame-starved' singers 
or corrupt entrepreneurs. ${ }^{12}$ This collaboration could risk losing the audience with which the band could create the 'energy flow' referred to by the same musician earlier. The new audience would have different expectations and musical aesthetics which are heavily devalued by the musician and associated with sexual luring.

When the same musician was asked to define 'quality,' he stressed 'the freedom of playing, the interaction of the band, the communication with the audience, the flow of energy.' When requested to elaborate on his understanding of energy and the conditions allowing an energy flow, he asserted that it is

[...] when the players are interacting and communicating, when they're not playing as units but for each other and for the collective music [his emphasis], when the audience receives the core of that creative force and responds in a way that uplifts the musicians and excites them. The necessary factor is an active interaction between the musicians, the physical space and the audience in an uninterrupted way. The commercial scene swallows music and its purpose of communication. They make artificial products that are meant to be consumed easily and digested fast. [Thános]

A first reading of the above testimony suggests a critique of genre. Thános seems to support the idea that jazz gigs, where interaction between musicians is accomplished through extended improvisation, facilitate a state of 'energy flow' more effectively than a staged pop music performance where the audience only focuses on their singing idol. I argue, however, that Thános's logic does not reveal an intention to defend the jazz

\footnotetext{
12 The negative portrayal of the power-holders of the music industry is far from rare in instrumentalists' utterances. These speech acts are part of a well-rehearsed rhetorical repertoire, common in personal interviews and in everyday discussions among the musicians with whom I have socialised. As I have argued elsewhere (Tsioulakis, 2011b), these declarations need to be seen as modes of 'discursive resistance' that help musicians restore some balance between their powerlessness in the music industry and their individual ideologies and imaginaries.
} 
genre; reversely, it concludes with jazz as the only genre that succeeds in accommodating his logic. Howard Becker has supported that jazz 'can be defined only as that music which is produced without reference to the demands of outsiders.' (1951: 136) Ingrid Monson's (1996) study has also illustrated the characteristics that render jazz improvisation a privileged terrain for interaction between musicians on stage. Discussing the methodology of oral history in jazz research, Burton Peretti has advocated that attention should be paid to the 'phenomenology of the interview' (2001: 593) that illustrates the parallels between musicians' styles of playing and way that they construct their histories. In accordance with Peretti's suggestion, I found that my informants' utterances often constructed a historical affiliation with their American counterparts, mobilized primarily by their shared ideals of performative sociality. It is, in other words, the perceived freedom of musical expression that appeals to Thános and explains his rhetoric resonance with musicians who lived half a century earlier and thousands of miles away from him. ${ }^{13}$

Eventually, the collaboration between S- and Rustik was established, numerous rehearsals were carried out, and the shows started in early December. The Glitz Club was hosted in a detached edifice in Thiseí, an upscale tourist area under the Acropolis. The exterior was covered by an enormous poster featuring $\mathrm{S}-$, leaving no chance of the event going unnoticed by the public. The interior was decorated in a New York theme with three levels of spectator seating directed towards a Brooklyn Bridge-replica stage. Rustik appeared on stage with Mick for their act for roughly forty minutes every night. Afterwards, they moved to the back of the stage to serve as backing instrumentalists for S-'s two-hour show.

\footnotetext{
13 Another interesting parallel could be drawn between the identification of Athenian jazzmen with archaic stereotypes of black subaltern musicians and their own social positioning as the 'underdogs' of the Greek music industry. However, the extent to which this would explain their aesthetic affinity with jazz music remains unclear, especially since the equation between American jazz music and racial/social identity, even in its peak as a subcultural music expression, is far from unproblematic (see Stowe, 1994).
} 
The show took place three nights per week for four months. Almost every show was completely sold out. About 400 audience members filled up the venue each night, consuming large quantities of extremely overpriced alcohol, cheering, singing along and taking pictures of their pop idol, while largely ignoring the other musicians on stage. ${ }^{14}$ The front tables, considerably more expensive, usually accommodated wealthy middleaged Athenians and often local celebrities. Crammed at the back of the venue, standing behind the main bar, males and females in their late teens enjoyed the concert while only paying the minimum entrance fee. A pop music show of this magnitude employs a great number of people with overlapping duties defined by a vague division of labor. Despite the fact that the pop singer serves as the center of everyone's attention, a crew of sound engineers, lighting technicians, musicians, and entrepreneurs is implicated in the process of building an 'ideal show.' Both the rehearsals and the performances can serve as a terrain for the analysis of power dynamics and strategies of control. For the purposes of this text, however, the focus will be on the structuring of authority on stage as facilitated by the use of sound technology.

In the past few years, most large Athenian music clubs have utilized a system of in-ear monitoring for musicians. According to this technique, the traditional system of individual speakers (sound monitors) for each musician has been substituted by a circuit of earphones. This independent system of sound monitoring gives each musician the ability to adjust the volume of every instrument and voice in their earphones. Furthermore, this technique makes possible the transmission of additional sound channels into the earphones, channels that the audience is not meant to hear, such as the metronome and some pre-recorded backing tracks. One of these sound channels is

\footnotetext{
${ }^{14}$ Strikingly, although the audience members cheered and were very lively whenever the main pop singer was on stage, his departure caused an instant disengagement with the music that was still being performed. The extravagant finale of the show, a mere few seconds after the pop singer had dissapeared from sight, was not met by even the slightest applause.
} 
used for what is commonly referred to as the maestrófono ${ }^{15}$. The word maestrófono describes a microphone used by the musical director of the show (who is typically one of the instrumentalists on stage) to give directions to the rest of the musicians who can hear him in their earphones while performing. This technology establishes a successful one-way application of authority. The musical director holds the power of directing the performance while possible objections from the lower-rank instrumentalists have no technological means to be even heard, let alone considered.

For the needs of S-'s show, two maestrófona had been allocated on stage. The first was used by S-'s musical director, Démis, and was channeled to everyone's earphones on stage, including $\mathrm{S}$ - , the musicians, the backing vocalists and the sound engineers. The second was used by Achilléas who had assumed responsibility as Rustik's musical director for their own act. Achilléas's maestrófono was only heard in the earphones of Rustik (the lower rank instrumentalists) and the sound technicians. Given the fact that the maestroffono served as the technological means through which authority was applied to musicians, a sketch of the stage positions tracking the channeling of the maestrófono could literally provide a visual depiction of the flow of power on stage. Figures 8.1 and 8.2 illustrate the direction of Achilléas's and Démis's maestrófona respectively. The sketches also visualize the existence of 'authority zones,' with their difference in magnitude for Achilléas as the musical director of Rustik, and Démis, the chief musical director. The spatial character of these authority zones was reinforced by a temporal one: Achilléas's authority was limited to the time periods when Démis was not on stage. In some instances, Achilléas's maestrófono was completely disabled as soon as Démis stepped on stage, and consequently his authority vanished.

\footnotetext{
${ }^{15}$ Maestrófono ( $\mu \alpha \varepsilon \sigma \tau \varrho \dot{\varphi} \omega \nu$ o) is a made-up word playing with the words mikéfófono (microphone) and maéstros (the musical director). It only exists within the occupational slang of professional musicians.
} 


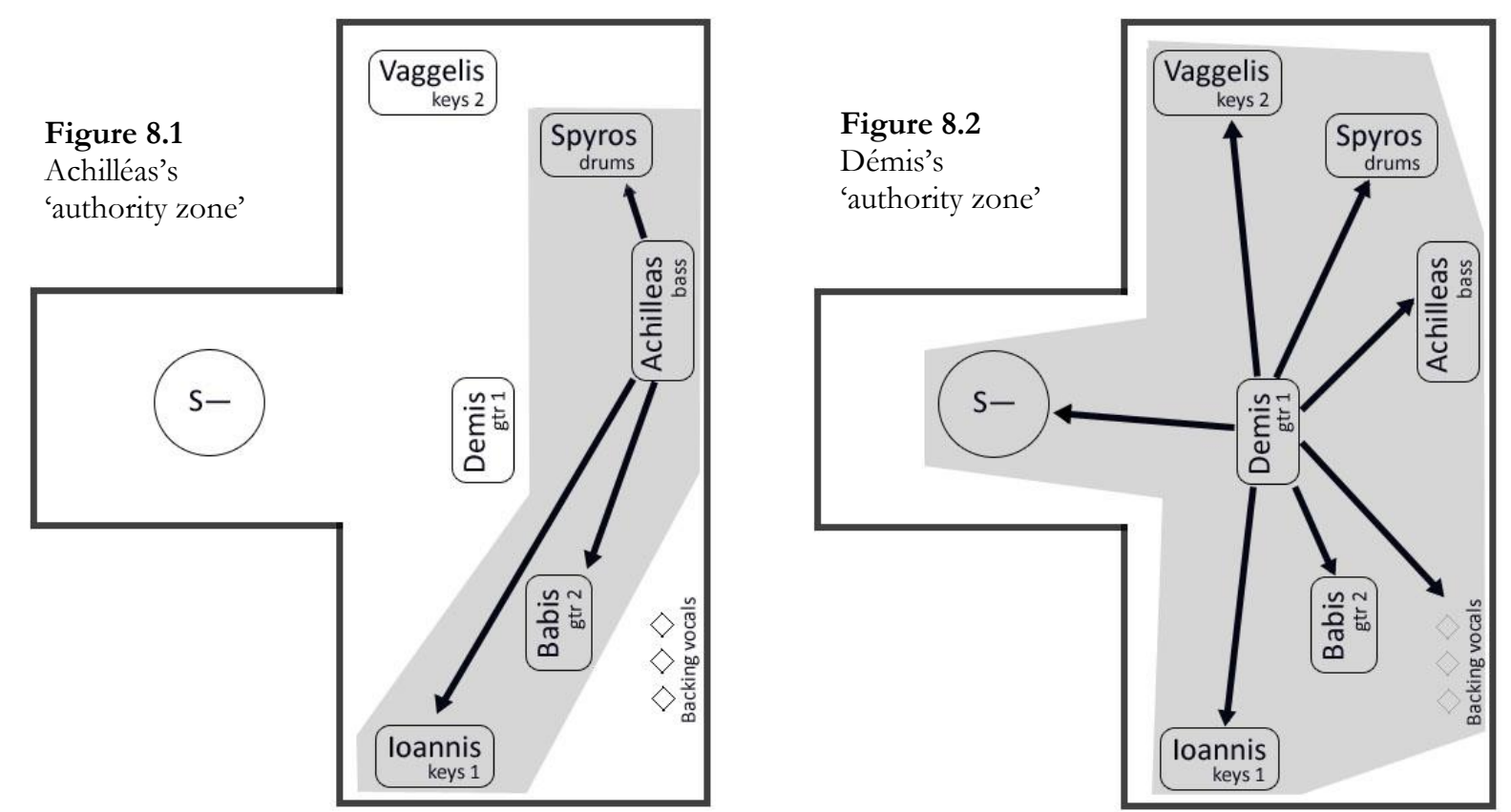

Understandably, the power dynamics created by the circumstances outlined above had a significant impact on the band's relationships. Cottrell has shown that orchestra conductors are perceived among professional classical musicians in London as 'the figures responsible for curbing their creative instincts, subduing their own musical personality.' (2004: 109) In a similar way, as soon as a member of a previously unstructured collective becomes the bearer of authority and directs the performance, the quality of his interaction with the others is altered. In the words of Bábis:

It was strange to have Achilléas as my superior in a band that we started long before he joined. It's not that I mind because he is younger but I didn't like him being rude to me on the maestrófono a few times. It annoyed me a lot. It also happened twice over the summer when we were playing with $\mathrm{T}$ Someone made a mistake and we messed up the whole piece, so I started laughing. So Achilléas went to his maestrófono and said "why are you laughing? Do you find this funny?" 
With Achilléas as a designated musical director, the band's power dynamics had changed. The egalitarian participation of the earlier mentioned performances was replaced by a complex web of authority and convention. Far from Thános's ideal of a flow of energy among freely communicating musicians, this show was defined by an advanced structure of obligations that represented an extreme example of musical labor. The question of the extent to which this is their space and sound is no longer relevant, since they fail to qualify as a homogeneous and collectively motivated group. They are, now, individuals situated within a structured scheme of authority and power. More significantly, this power structure was caused by a spatial and sonic arrangement which hindered the valued interaction between the instrumentalists in favor of the pop genre's demand for complete attention to the singer.

This is an example of how the ideal of performative mutuality is rendered nonaccomplishable due to the disjuncture between the members' aspirations. Typical of a large-scale urban performance venue, the Glitz Club caters the entertainment needs of a wide array of people carrying different aesthetic dispositions, music ideologies, and consumer demands. In the context of the popular industry, the success or failure of the event's sociality depends on the synthesis of music-making, entrepreneurialism, and consumption. The increased division of labor and the authority scheme necessary for this kind of productions, however, are experienced by the musicians as factors of alienation. Accordingly, although from the point of view of entrepreneurs and audience members this could be described as an entirely successful performance, the instrumentalists portray it as meaningless 'work'. 


\section{Discussion: performance, power and 'quality'}

The examined cases present three performances placed by the participants on different positions along a conceptual spectrum between work and play. Their memories of enjoyment or frustration and their assessment of success or failure are entangled in a narrative of power. In the first instance at the Alma Libre Club, the band members hold the power over the production of the music yet, due to lack of control of the sound volume and the arrangement of space, they fail to include the audience in the communicative flow, a fact resulting in feelings of isolation and fragmentation. The second example features the band in a triumph of power which allows them to achieve the circumstances necessary for their ideal performance. The third scene demonstrates the impact of a fixed power structure on the band's internal dynamics as its members enter the domain of high-rank professional music-making. The contrasting testimonies suggest an understanding of the different performative contexts along a continuum of 'work' vs. 'play' that can be schematically depicted as follows:

\begin{tabular}{|ll|}
\hline Playing & Working \\
\hline High quality & Low quality \\
\hline Power & Powerlessness \\
\hline Creativity & Labor \\
\hline Energy flow & Energy interruption \\
\hline Communication/mutuality & Alienation/fragmentation \\
\hline Jazz & 'Mainstream' popular music \\
\hline
\end{tabular}

Table 8.1 - Continuum of 'work' vs. 'play' 
The above quasi-structuralist list of dualisms does not intend to suggest that musicians constantly mobilize these divisive mechanisms in order to fit every event to one or the other category. Rather, it depicts some of the conceptual poles that are interchangeably evoked in the everyday discourse of music evaluation. In fact, musicians would argue that most performance occasions fall somewhere in the grey areas between these two extremes. But even then (or most importantly then) it is through these dualisms that they assess the value of the emergent music sociality. In their attempt to transform an 'affinity interculture' (Slobin, 1993) of jazz music into a vibrant subculture, jazz musicians in Athens construct a complex discourse of musical and performative quality. This discourse needs to be approached in a phenomenological manner. It focuses on experience, is negotiated through different ways of being in the musical world, and is portrayed as entirely dependent on group dynamics and participatory conventions. In the view of jazz musicians, quality can only be achieved through mutual engagement.

This is closely linked to Victor Turner's idea of communitas as 'the abrogation, negation, or inversion of the normative structure in which its participants are quotidianly involved.' (1982: 47) In the same way, performances of mutual play can only appear in the liminal spaces of structured work, and it is in those spaces that they become meaningful. Play is 'liminoid' (Turner, 1982) insomuch as its objective is to momentarily subvert the existing power structures. This resonates with Schechner's metaphor of 'creases' as 'signal areas of instability, disturbance, and potentially radical changes in the social topography.' (1988: 184) Play is where the otherwise powerless instrumentalists become the masters of the game and unleash their creative energy in a flow that renders their experience meaningful in itself. This social topography, as Schechner notes, more often than not finds a parallel in urban topography; the contrast between the attention-seeking Glitz building and the invisibility of The Attic is not deprived of meaning. Urban space, similarly to performative space, serves as a ground 
on which subcultural and supercultural (Slobin, 1993) formations strive for domination. It is not, thus, coincidental that the subversion of power, the achievement of 'true musical quality', occurs in liminal spaces (the 'creases') of urban topography such as The Attic.

We should, however, bear in mind that these views of quality are far from uncontested. As Bourdieu has noted, 'it is their present and past positions in the social structures that biological individuals carry with them, at all times and in all places' (1977: 82). The communitas of play emerges through a collective experience that implicates the subjectivities of various actors who are, as Bourdieu argues, by definition charged with power of various magnitudes. Seen through the eyes of Athenian jazzmen, success or failure of the performance relies upon the balance of those subjectivities. The achievement of communitas, therefore, depends on the successful, albeit fleeting, transcendence of the structural dispositions in favor of a sense of selfless unity. This is what Turner defines as anti-structure (Turner, 1982). In the case described, the recurring changes of power dynamics have constructed a situation where an anti-structure is hardly achievable for the band. Thános, the member who valued 'energy flow' most as a precondition for musical enjoyment, illustrated with his departure the belief that this collective has entered a stage where no kind of communitas can ever be accomplished.

\section{Conclusion: performative mutuality}

Through the examination of the above three music settings involving the same collective of instrumentalists, this chapter has attempted a sociomusical analysis of performance and its inherent negotiations of power. It has shown that the construction of musical ideals such as performative mutuality, even when rhetorically portrayed as universal social qualities or undeniable artistic values, they are still negotiated through 
hierarchical milieux that are in essence local and interpersonal. Therefore, the meaning that musicians attach on those values needs to be investigated through close ethnographic work and experiential description. Moreover, in accordance with Steven Feld, this chapter has illustrated the way in which local ideologies concerning musical quality, constitute and reflect 'sociological models of and for musical realities' (1984: 404), namely the hierarchies within musical work. Moreover, the analysis of play and its prerequisite of 'energy flow,' accounts for the negation of social positions (Roseman, 1984: 411) in liminoid performances. Transposing Feld's (1984), Roseman's (1984) and Blacking's (1973) views on the link between the musical and the social, however, to the urban context, entails an additional challenge. The analysis needs to speak to the plurality of musical sensibilities and the struggles between them as they are manifest in interpersonal and performative behavior. This is what I have tried to accomplish in this text.

The notion of 'performative mutuality' goes a long way in describing the value that my informants ascribed to successful participation in music. Moreover, I find the term useful in capturing the modalities of music production and consumption that exist within the city of Athens. In the view of Athenian jazz-trained instrumentalists, the quality of a performance depends on the achievement of mutual engagement that transcends the individuals involved. However, as this chapter has suggested, this fragile performative mutuality can only be accomplished through the explicit control of space and sound. Play and 'flow' experiences are far from individualist universals; they are phenomena deeply rooted in local cultural and ideological constructs, which are facilitated or inhibited by fields of social powers. Thus, the ideal of performative mutuality stands simultaneously as a testimony to a cosmopolitan imaginary of the emancipated artist, and a locally specific critique of musical value. Hidden behind this discourse lays a cultural clash between diverse musical groups and a network of entrepreneurs and consumers within the urban Greek capital. The case studies 
employed in this article have offered three snapshots of how this clash becomes dramatized, while the individual utterances have shed light on the rhetorical constructions that accompany it. In the course of this analysis, I have argued that the continuously changing social circumstances that define urban music-making can only be revealed through close attention to the microcosm of the performance event.

The association of mutuality and communitas with unity, however, can be somewhat simplistic, as it is often used as a means for separation. The liminoid phenomenon frequently concerns a 'self-selecting group of people who share similar cultural aspirations, and whose participation in the event suggests a desire to withdraw, temporarily, from the highly ordered society they have left.' (Cottrell, 2004: 156) In other words, when examining an act of mutuality, one needs to thoroughly consider who is excluded. This is where the schematic continuum presented above becomes useful: along with defining what 'quality' in performance is, it identifies the settings and notions against which it operates as an anti-structure. Consequently, the 'quality' performance will never transcend its liminoid character, as it is generated by a specific musical imaginary that exists in constant conflict with numerous collective imaginaries of the Greek mainstream. It is in this frustrating reality that the 'quality' discourse serves for the Athenian jazz musicians as both their conviction and their revenge.

\section{Works Cited}

Becker, H.S. 1951. 'The Professional Dance Musician and His Audience'. The American Journal of Sociology, vol. 57, no. 2, pp. 136-144.

Blacking, J. 1973. How musical is man? Seattle: University of Washington Press.

Bourdieu, P. 1977. Outline of a theory of practice. Cambridge England ; New York: Cambridge University Press.

Christian, H. 1987. 'Convention and constraint among British semi-professional jazz musicians'. In A.L. White (ed). Lost in music : culture, style, and the musical event. London ; New York: Routledge \& K. Paul. 
Cottrell, S. 2004. Professional music-making in London: ethnography and experience. Aldershot, Hampshire, England; Burlington, V'T: Ashgate.

Cowan, J.K. 1993. 'Politics, identity and popular music in contemporary Greece'. Kampos: Cambridge papers in modern Greek, vol. 1, no. 1, pp. 1-22.

Csikszentmihalyi, M. 1990. Flow : the psychology of optimal experience. 1st edn. New York: Harper \& Row. Feld, S. 1984. 'Sound Structure as Social Structure'. Ethnomusicology, vol. 28, no. 3, pp. 383-409.

Holt, F. 2010. 'The economy of live music in the digital age.' European journal of cultural studies 13, vol. 13, no. 2, pp. 243-261.

Kallimopoulou, E. 2009. Paradosiaka : music, meaning and identity in modern Greece. Farnham, England ; Burlington, VT: Ashgate.

Keil, C. 1994. 'Participatory discrepancies and the power of music'. In C. Keil \& S. Feld (eds). Music grooves : essays and dialogues. Chicago: University of Chicago Press.

Monson, I. 1996 Saying something: jazz improvisation and interaction. Chicago: University of Chicago press. Papanikolaou, D. 2007. Singing poets: literature and popular music in France and Greece. London: Legenda.

Peretti, B.W. 2001. 'Speaking the Groove: Oral History and Jazz.' Journal of American History, vol. 88, no. 2, pp. 582-595.

Qureshi, R.B. 1987. 'Musical sound and Contextual Input: A Performance Model for Musical Analysis'. Ethnomusicology, vol. 31, no. 1, pp. 56-86.

Roseman, M. 1984. 'The Social Structuring of Sound: The Temiar of Peninsular Malaysia'. Ethnomusicology, vol. 28, no. 3, pp. 411-445.

Schechner, R. 1988. Performance theory. New York: Routledge.

Slobin, M. 1993. Subcultural sounds: micromusics of the West. Hanover, NH: University Press of New England.

Small, C. 1977. Music, society, education: a radical examination of the prophetic function of music in Western, Eastern and African cultures with its impact on society and its use in education. London: Calder.

Stowe, D. W. 1994. Swing changes: big-band jazz in New Deal America. Cambridge, Mass: Harvard University Press.

Tragaki, D. 2007. Rebetiko worlds. Newcastle: Cambridge Scholars.

Tsioulakis, I. 2011a. 'Jazz in Athens: frustrated cosmopolitans in a music subculture.' Ethnomusicology Forum, vol. 20, no. 2, pp. 175-199. 
Tsioulakis, I. 2011b. 'At first I saw it as a toy: life stories, social consciousness and music ethnography.' In K. Egan \& F. Murphy (eds.) The Value of Ethnographic Writing. Irish Journal of Anthropology Special Issue, vol. 14, no.1, pp. 19-28.

Turner, V.W. 1982. From ritual to theatre: the human seriousness of play. New York City: Performing Arts Journal Publications.

White, A.L. 1987. 'A professional jazz group'. In A.L. White (ed). Lost in music : culture, style, and the musical event. London; New York: Routledge \& K. Paul. 